\title{
A CULTURAL FIT IN COOPERATION - RECOGNITION OF THE CULTURAL FACET OF GAME DEVELOPERS
}

\author{
Patrycja Klimas \\ Wrocław University of Economics, Wrocław, Poland \\ e-mail: patrycja.klimas@gmail.com \\ ORCID: 0000-0002-3912-7389
}

\section{(C) 2019 Patrycja Klimas}

This is an open access article distributed under the Creative Commons Attribution-NonCommercial-NoDerivs license (http://creativecommons.org/licenses/by-nc-nd/3.0/)

DOI: $10.15611 / \mathrm{ms} .2019 .1 .01$

JEL Classification: M14, M21

\begin{abstract}
The relational view perceives cultural fit as a factor allowing cooperation and influencing its performance. It is believed that knowledge about the dominant cultural profile allows organizations to adjust their own cultural profile, and thus increase the cultural fit and improve the cooperation process. The role of cultural fit is of particular importance in markets favoring cooperation and networking, thus our investigation has been sited within the video game industry. Our explorative findings reveal the most typical cultural features, cultural competitive values and models of culture of video game developers. In particular they show, there are differences in cultural aspects between developers of premium and F2P games. In general, organizational cultures of game developers are based mainly on flexibility and best suit the adhocracy culture.
\end{abstract}

Keywords: cooperation, organizational culture, cultural fit, cultural similarity, cultural compatibility.

\section{Introduction}

Organizational culture is one of the most explored characteristics of organization in management science since its introduction to the academic debate in late 1970s and early 1980s [Hofstede 1998]. Nonetheless, it is continuously attracting growing interest among researchers, calling for further exploration [Sułkowski 2008], however in new perspectives and contexts [Gregory et al. 2009].

Given the dominant perspective in strategic management, namely the relational view on firms' competitive advantage, it seems interesting to investigate the issues related to organizational culture as the cultural fit of cooperating partners - in dyads and networks - is acknowledged as a significant (or even sine qua non) condition for cooperation establishment and performance [Pothukuchi et al. 2002; Karsmakers 2010; Bauer, Matzler 2014]. Just recently there have started to appear suggestions indicating the need for the investigation of particular features and manifestations of different cultural features and models of organizational culture in the context of interorganizational cooperation [Klimas 2014] and also cooperation among business rivals [Strese et al. 2016].

The claims about the important role of cultural fit for cooperation have given grounds for this paper. Using explorative, quantitative study it aims at the identification of the cultural profile of video game developers (VGDs). The reasoning for focusing on VGDs is as follows: the growing need and openness for intra-industry cooperation [Marchand, HennigThurau 2013]'; the very cultural nature of the video

\footnotetext{
${ }^{1}$ In light of the latest report on the Polish game sector [Bobrowski et al. 2018] about 32\% of Polish developers are not using self-publishing, while $25 \%$ of game developers are willing and interested in publishing games developed by other game studios.
} 
game industry (it is part of the creative and culture sector, playing a significant role in the digital culture); cooperation within the video game industry appears mainly between and among video game developers displaying cultural similarities (see Table 8 in: [Karsmakers 2010, p. 50]). Our exploration of the cultural features, competing values and models of organizational cultures applies the most popular research approach [Gregory et al. 2009] based on the concept of Competitive Value Framework [CVF; Cameron, Quinn 2003].

\section{Organizational culture and interorganizational cooperation}

Organizational culture is understood as an intangible and strategic resource [Barney 1986] rooted in "the values, beliefs, and assumptions held by organizational members" [Denison 1996, p. 624] reflected in the specific organizational way of perceiving and interpreting the surrounding reality. As expressed by Weber, Shenkar and Raveh, those aspects are seen as taken-for granted within the boundaries of an organization [Weber et al. 1996, p. 1216], i.e. at an organizational - not individual - level [Hofstede $1998]^{2}$. In a broader sense, organizational culture is an integral component of the organizational, collective cultural mindset shaping the general sense-making/ meaning-making framework being "a set of mental representations or cognitive schema containing culture-congruent content, cognitive procedures, and goals" [Oyserman 2011, p. 165].

In strategic management organizational culture is acknowledged as a significant factor directly influencing firms' growth [Denison 1996] and sustainable competitive advantage [Barney 1986]. Furthermore, it can be seen as a factor indirectly affecting firms' competitive advantage through its direct impact on such success factors as return on investment, firm performance, organizational creativity and innovativeness, social capital and employee satisfaction, knowledge management, or interorganizational cooperation [Klimas 2016].

Given the relational view, organizational culture is acknowledged as a factor allowing, triggering, accelerating and improving interorganizational cooperation. Indeed, is has been shown as a success factor for cooperation [Xiao, Tsui 2007] coopetition [Chin et al. 2008; Strese et al. 2016], and networking [Noorderhaven et al. 2002]. Indeed, there is empirical evidence for the positive influence of organizational culture for cooperation [Klimas 2014], its performance [Pothukuchi et al. 2002] also in the long term [Bauer, Matzler 2014]. It is argued however, that different models of organizational culture differently influence the benefits taken from cooperation [Xiao, Tsui 2007].

The main emphasis on cultural issues in the relational stream of research is placed on the cultural fit of cooperating partners ${ }^{3}$. From the very beginning, the cultural fit together with the strategic match of the partners are shown as a significant factor of cooperation establishment and resilience, hence the former is shown as having an "equal, if not greater importance" [Cartwright, Cooper 1993, p. 59] for cooperation success in the long term. Surprisingly, even though cultural fit used to be popular in studies in the field of mergers and acquisitions (M\&A), it has remained an "ill-defined" expression [Cartwright, Cooper 1993, p. 60]. It is highlighted that in that particular area of strategic management it is hard to find any sound definition of cultural fit [Weber et al. 1996]. However, following and transferring prior considerations from M\&A literature to the relational view approach, the cultural fit in a general perspective (labelled also as cultural compatibility, cultural coherence) can be seen as a "degree of convergence of values, behavioural standards and artefacts" [Klimas 2016, p. 93] followed, believed or adopted by cooperating organizations. In a more detailed and operational perspective, the cultural fit is suggested to be perceived as the extent to which the dominant culture types of the partnering organizations, including their cultural features and main organizational characteristics considered under their specific types of organizational cultures do overlap [Cartwright, Cooper 1993].

Just recently the cultural fit in an interorganizational context has started to attract the attention of researchers following the relational view on competitive and cooperative advantage [Klimas 2016]. Up till now partner fit has been empirically proven as a key determinant for cooperation success [Karsmakers 2010] as it directly influences the possibility of achieving the effect of synergy [Bauer, Matzler

\footnotetext{
${ }^{2}$ It is claimed that organizational culture differs from the cultural climate of an organization as the former is considered at organizational level, hence the latter is seen as bridging organizational and individual ones [Hofstede 1998].

${ }^{3}$ It is worth noting that cultural fit covers two separate constructs, namely the national cultural fit and organizational cultural fit [Weber et al. 1996]. As shown in prior research, both types of cultural fit matter in cooperation, hence the positive role of organizational cultural fit is much more distinctive and significant for the satisfaction from interorganizational cooperation [Pothukuchi et al. 2002].
} 
2014, p. 274] $]^{4}$. Furthermore, as suggested by Sikorski [2002], organizations oriented at cooperation not only take benefits from cultural fit but also respect cultural dissimilarities and try to use those dissimilarities to learn or improve own organization. In other words, cultural fit impacts not only the cooperation process (see the extensive theoretical evidence discussed in Cartwright, Cooper 1993) but also the internal activity, resource base and capabilities of the cooperating partners. For instance, as claimed by Karsmakers [2010, pp. 16-17], managerial actions aimed at mutual cultural adjustments (e.g. cultural training) improve the cooperation performance and leverage relational capabilities of the partners. Last but not least, the research shows the cultural misfit of partners as one of the crucial reasons for cooperation's failure [Bauer, Matzler 2014] which strengthen the reasoning of the need for taking care of the cultural fit in an interorganizational context.

Summing up, cultural fit considered between cooperating partners does play a significant role for cooperation and the cooperating partners. Nonetheless, in business practice cooperation in dyads is more often replaced by cooperation in networks [Czakon 2012]. As a result, the success of cooperation depends more and more on the general fit of all partners (i.e. the fit in the overall strategic network, business ecosystem, supply chain, etc.) than a pure individual fit considered between two particular actors [Karsmakers 2010]. In that perspective, the recognition of typical, suitable and dominant cultural features, competitive values and models of culture within the entire - potential or exploited - networking environment seems to be valuable. We claim that such recognition frames the cultural profile into which an organization ought to fit if it is interested in establishing cooperation or optimizing the performance of the cooperation which has been already established.

\section{Research design}

Linking the growing openness and increasing need for interorganizational cooperation with the importance of cultural fit of cooperating partners, this study aimed at the recognition of the most typical and dominant cultural characteristics - including cultural features, cultural competitive values, cultural models - of video game developers. Due to the industrysensitive nature of organizational culture [Ozeren et al. 2013], we decided to narrow our focus to one industry, namely the video game industry as it still remains under-researched in management sciences [Marchand, Hennig-Thurau 2013].

Organizational culture is a complex construct, related to mentality and cognition and thus hard to measure objectively and directly. Therefore, to assess the cultural facet of VGDs, our measurement covered 8 questions related to 8 cultural features considered under CVF [Gregory et al. 2009]: (1) flexibility, (2) discretion and dynamism, (3) stability, (4) external orientation, (5) differentiation, (6) control, (7) internal orientation, and (8) integration. These features were used to identify the most characteristic:

- cultural competitive values amongst the following: flexible structure, stable structure, external focus, and internal focus;

- cultural models amongst the following: clan (internal focus and flexibility), hierarchy (internal focus and stability), market (external focus and stability), and adhocracy (external focus and flexibility).

The questionnaire was based on the 7-point Likert scale (range from 1 - totally disagree to 7 totally agree; two reverse questions were included). Note however, that in the analytical part only the answers from 5 to 7 were processed as these marks reflected the possession of particular cultural features (i.e. were used as a proxy of their suitability).

The data was collected using a mix-method approach including CAWI (19 companies filled in the questionnaire online) and PAPI (14 companies were interviewed during Digital Dragons 2018 in Cracow). As the aim of the study was explorative, there was no need to make the sample representative. Note however, that the sample of 33 represents approximately $10 \%$ of the Polish game developers' population ${ }^{5}$.

The gathered data was analysed using descriptives, namely the mean and frequency. However, as the interpretation of mean in the case of studies based on ordinal scale might be misleading [Bedyńska, Książek 2012], the results using mean were considered only as supportive. The main findings and conclusions were based on the frequency of the positive identifications of particular cultural features.

\footnotetext{
${ }^{4}$ Interestingly, the research run by F. Bauer and K. Matzler [2014] revealed the negative and significant impact of organizational cultural fit on the level and speed of formal integration. The authors suggest however, that in the case of partners displaying similar organizational cultures, formal integration mechanisms might be replaced by informal and social coordination mechanisms. If this is so, organizational cultural fit gives another benefit as it allows partners to make savings on the mutual protection of individual interests.

${ }^{5}$ According to the newest report on the Polish game industry ordered by the Ministry of Culture and National Heritage, there are 311 game developers actively operating in Poland [Bobrowski et al. 2018].
} 
The exploration of cultural issues was divided into two types of video game developers, namely those offering mainly games based on the premium model of monetization and those developing mainly F2P games. The reasoning for the adopted distinction is twofold.

First, all of the national [Bobrowski et al. 2018] and global (see e.g. reports prepared by NewZoo, SuperData, $\mathrm{PwC}$, or Accenture) industry reports highlight significant differences (in terms of management, leadership style, targeted customers, types of delivered games, turnovers, to name a few) between these two groups of VGDs. Generally, the business models based either on the premium or on freemium monetization model significantly different not only in terms of managerial approach and financial strategies, but also in terms of the level of attention paid to technological quality, artistic value, traditional or digital distribution, and return on investment from developed games.

Second, given the cultural view it seems that paid and F2P games do differ in terms of the possible "cultural impact" on gamers. Paid games are usually focused on telling a story using a specific way of narrative, suitable music and meaningful graphics, and usually a deep history in the background (thus they are much more immersive, e.g. The Witcher 3), hence F2P games are usually developed just for fun without a deep sense behind them (they are much more entertaining, e.g. Candy Crush). In that perspective, paid games create more opportunities for developers to implement some cultural message or connotation inside the game.

\section{Discussion of findings}

In the general perspective, the collected data shows flexibility as dominant (m: 5.91; f: $96.97 \%)^{6}$, hence control (m: 2.27; f: $12.12 \%$ ) as the least typical cultural features of VGDs see Table 1. Interestingly, both of them are perceived as extraordinarily strongly shaped by the collective norms and beliefs appreciated within the organization [Barney 1986, p. 656].

The results of the transposition of features into the cultural competitive values reveal the flexible structure as the most typical (m: 7.71 ; $\mathrm{f}: 87.88 \%$ ), whereas the stable structure as the least characteristic (m: 2.58 ; f: 12.12\%) for the researched companies. Both of the above findings strongly suggest the leading role of flexibility in the organizational culture of video game developers. It supports the prior findings from Holland, showing flexibility as of particular importance for VGDs due to the turbulent nature and high innovation pressure typical for the video game industry [Karsmakers 2010, pp. 66-68].

We argue that video game developers differ in terms of cultural aspects as these aspects are conditioned by the adopted business models significantly based on the general approach to the monetization models used in developed games. Indeed, our findings show that the cultural facets of game developers offering paid and freemium games are different, see Figure 1.

Given our data, VGDs with dominant monetization based on freemium model:

- most often reflect flexibility and external orientation (f: $94.15 \%$ ) and adopt a flexible structure (f: $79.41 \%$ );

- do not appreciate control (f: $0 \%$ ) and to the smallest extent adopt a stable structure (f: $14.71 \%$ ).

At the same time, the developers generating revenue from selling paid games:

- are very flexible (f: $100 \%$ ) and usually take on a flexible structure (f: $96.88 \%$ );

- do not appreciate stability (f: $0 \%$ ) and their competitive value is the farthest from a stable structure $(9.38 \%)$.

The above differences may result from the much higher uncertainty faced by the developers focused on the premium monetization model. This is so, as the process of development of premium games is more demanding (in terms of the level of expenses, necessary

Table 1. Summary of results obtained for all researched companies $(N=33)$

\begin{tabular}{|l|c|c|c|c|c|c|c|c|}
\hline \multicolumn{1}{|c|}{ Cultural features } & Flexibility & $\begin{array}{c}\text { Discretion \& } \\
\text { dynamism }\end{array}$ & $\begin{array}{c}\text { External } \\
\text { orientation }\end{array}$ & Differentiation & Stability & Control & $\begin{array}{c}\text { Internal } \\
\text { orientation }\end{array}$ & Integration \\
\hline Mean & 5.91 & 5.52 & 5.03 & 4.52 & 2.88 & 2.27 & 5.12 & 4.82 \\
\hline Positive marks & $96.97 \%$ & $78.79 \%$ & $72.73 \%$ & $48.48 \%$ & $15.15 \%$ & $9.09 \%$ & $66.67 \%$ & $66.67 \%$ \\
\hline Cultural competitive values & \multicolumn{2}{|c|}{ Flexible structure } & \multicolumn{2}{|c|}{ External focus } & Stable structure & Internal focus \\
\hline Mean & \multicolumn{2}{|c|}{5.71} & 4.77 & 2.58 & \multicolumn{2}{c|}{4.97} \\
\hline Positive marks & \multicolumn{2}{|c|}{$87.88 \%$} & \multicolumn{2}{|c|}{$60.61 \%$} & $12.12 \%$ & $66.67 \%$ \\
\hline
\end{tabular}

Source: own study. 

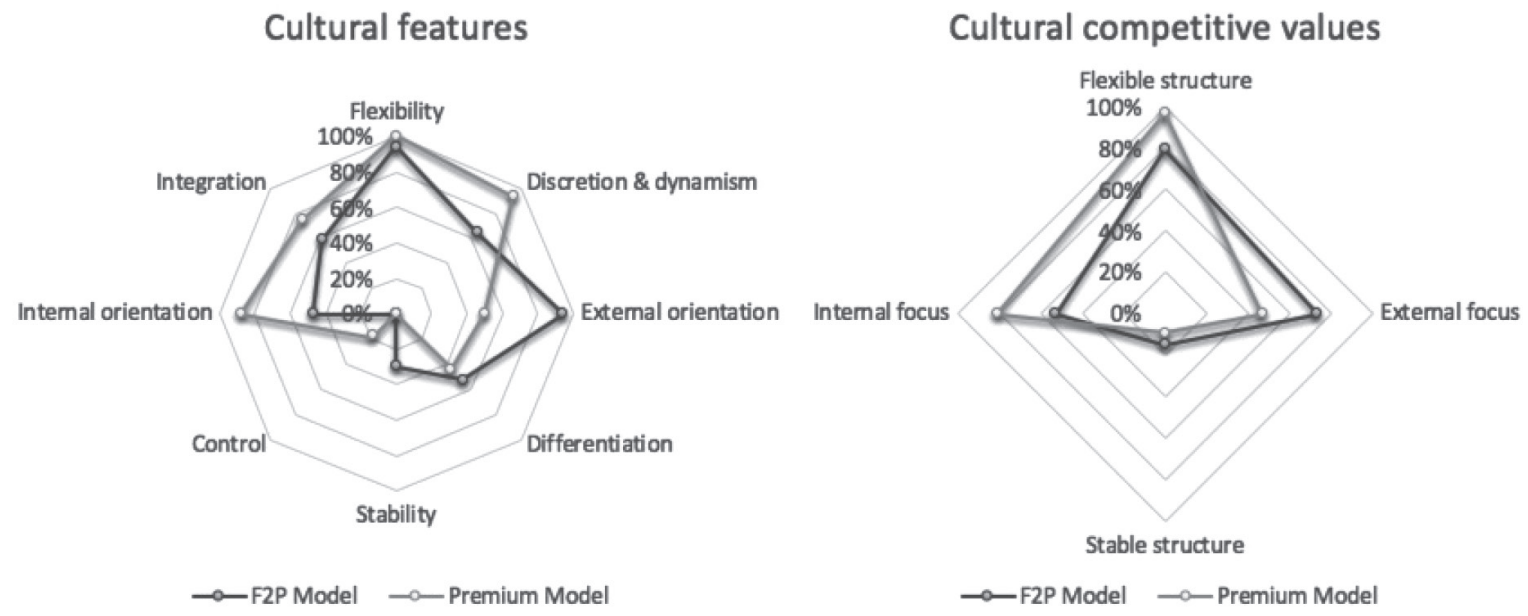

Figure 1. A comparison of cultural features and competitive values of video game developers with the dominant premium or F2P monetization model

Source: own work.

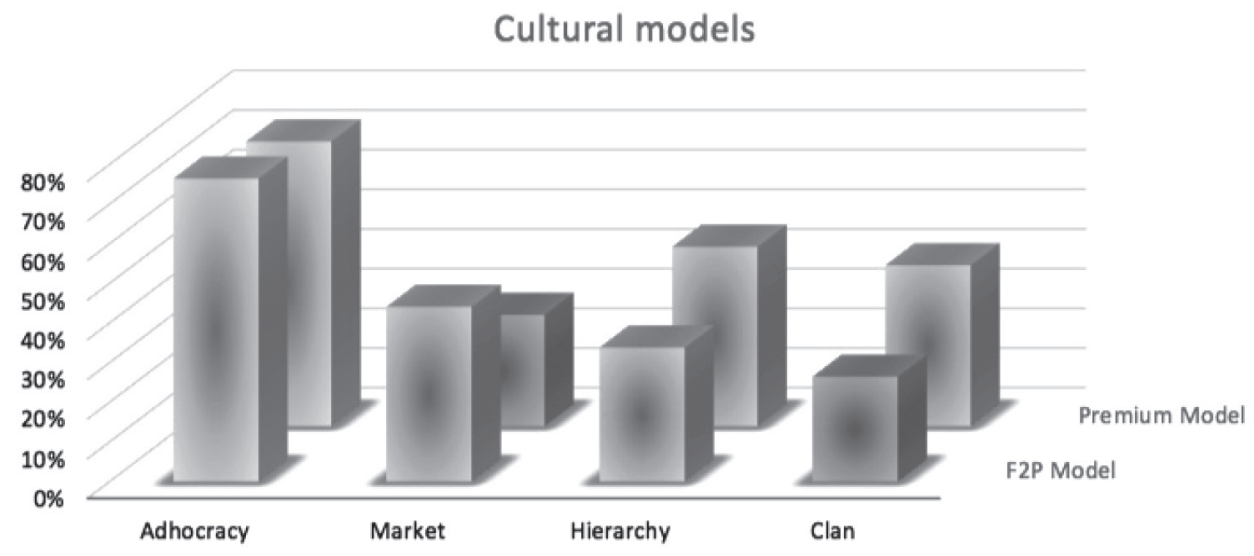

Figure 2. Cultural models for video game developers with the dominant premium or F2P monetization model

Source: own study.

development capabilities, basic technological and artistic content) and time-consuming (it takes around two to five years), thus it is much more expensive and uncertain. Furthermore, those games - in contrast to F2P games - ought to be much closer to radical or even disruptive innovation as the inclusion of any improvements and enhancement in "a new paid game" would not be enough to achieve market success.

Summing up, developers focused on paid games are shown as more internally oriented, paying greater attention to internal integration, focused on discretion and dynamism. Simultaneously, studios concentrated on F2P games seem to be more externally oriented and paying slightly more attention to stability. The obtained findings may be reasoned by lower resource bases, weaker market power, lower ability to face innovation pressure, and slower time-to-market skills of developers with the dominant F2P model. In business practice, these companies are usually smaller in terms of turnover, number of employees, scope of activity, and recognition in the gaming community [Kondycja polskiej... 2018; Global Games... 2018]. Moreover, developers focused on F2P games presuppose an ongoing interaction with other developers and gamers in order to create, develop or improve the game content as well as to take other benefits from the social effects [Feijoó 2012, pp. 77-78]. This is so as this type of games is perceived as a service, not as a product [Bobrowski et al. 2018].

The last but not the least step was aimed at the recognition of the most and the least typical models of organization culture. The intersection of cultural competitive values shows adhocracy cultural model as the most characteristic for game developers using both the premium and freemium model of monetization see Figure 2. Such a result should not be surprising as this 
model of culture is seen as typical for organizations tending "to be entrepreneurial, visionary, innovative, and creative" [Eckenhofer, Ershova 2011, p. 38]. Furthermore, it supports prior studies showing the adhocracy model as the most suitable for organizations focused either on short-term and periodic interaction or on longitudinal cooperation [Strese et al. 2016].

Moreover, there is a difference in terms of the least typical cultural model. Even though the clan culture is least suited to developers with the dominant F2P model, it fits least those with dominant premium on the market model of culture. First, the lowest suitability of the clan culture for some developers of F2P games results mainly from their greater focus on external rather than internal integration (see Figure 1). These developers are more open for (or pushed into) interorganizational cooperation, hence the clan model' shapes and favors dense inter-organizational social networks [Eckenhofer, Ershova 2011]. Second, the market model might be the least suitable for developers of premium games as they:

- have to pay greater attention to internal focus due to their size and global market power [Bobrowski et al. 2018];

- face greater uncertainty as their games are much more expensive and complex in production, the development processes are much longer (e.g. usually there is a few-year's difference between expenditure and profit), games ought to be rather radical than incremental, business models usually are based on one or two leading titles only (see the case of the CD Project completely functioning around one game series for almost 15 years) ${ }^{7}$.

\section{Concluding remarks}

The interorganizational stream of research points at cultural fit as an important factor for cooperation. However, it is assumed that the cultural facets of the cooperating partners do not have to be the same, rather they should be similar and compatible [Chin et al. 2008; Klimas 2016], as partners should express reciprocal understanding, acceptance and respect of the adopted models of organizational cultures. This remains in line with the reasoning showing organizational culture as a strategic resource. In that vein, even though organizational culture - seen as a strategic resource - ought to be inimitable [Barney 1986] in a cooperation context, particular partners may try to follow and adjust their organizational cultures to the cultural leaders appreciating the values, norms, beliefs, cultural features and models favouring cooperation. It is reasoned that such cultural adjustments should increase the general stability [Klimas 2016] and synergistic effect [Bauer, Matzler 2014] of cooperation.

Our findings contribute to the cooperation and networking literature as they reveal the dominant cultural features, competitive values and models of organizational cultures of video game developers - companies more often pushed into cooperation processes. In particular, regardless of the type of VGDs we revealed flexibility, flexible structure and model of adhocracy as the dominant cultural aspects. At the same time, the general results point at the marginal role of stability, which from the perspective of claims about the instabilities of cooperation processes [Czakon 2012, pp. 71-78] shows VGDs as opportune for taking benefits from cooperation and networking. Furthermore, our results reveal some significant differences between VGDs with the dominant premium or freemium model in terms of shaping the cultural fit. In particular, companies using the F2P model ought to be more internally oriented and avoid the clan model of culture if they are interested in taking optimal benefits from intraindustry cooperation. Simultaneously, it seems that firms focused on delivering paid games should be more internally focused, hence not adopt the market cultural model.

As a practical contribution we see the identified dominant cultural features, competitive values and models as valuable for video game developers. First, these cultural issues can be seen as selection criteria when choosing partner(s) for cooperation. Second, they can be perceived as the targeted directions of their own cultural adjustments if the company is interested in intra-industry cooperation, including both direct (with the same type of VGDs) or indirect (with VGDs with a different dominant model of monetization) coopetition.

We are aware that our study suffers from some limitations which narrow the possibilities of drawing general conclusions, e.g. sample size, industry and national context, yet this study was aimed at exploration not at generalization.

Our investigation was based on the basic assumptions of CVF. The applied approach, even though the most popular in the field, has been developed outside the relational view and networking

\footnotetext{
${ }^{7}$ Given the prior research on Polish game developers, the majority of those with the dominant premium model (58\%) work on 1-2 game projects simultaneously, hence the greatest part of those with the dominant F2P model (48\%) work simultaneously on 3-5 projects [Bobrowski et al. 2018].
} 
concept and thus it lacks consideration of the cultural compatibility. Furthermore, it seems to focus fragmentarily on the integral components of seminal definitions (e.g. [Denison 1996; Hofstede 1998]) of organizational culture. Therefore, in further research we suggest to add to CVF the third continua related to shared norms, values, beliefs and assumptions. This stays in line with Ozeren, Ozmen and Appolloni [2013, p. 491], who claim that cultural tightnesslooseness may be important for the exploration of the outputs and performance of relationships. Moreover, given the obtained results, it would be interesting to focus on examining the quite low suitability of differentiation which is perceived as a specific feature of the mobile segment of the games industry [Dymek 2012, p. 37].

\section{Bibliography}

Barney J.B., 1986, Organizational culture: can it be a source of sustained competitive advantage?, Academy of Management Review, 11(3), pp. 656-665.

Bauer F., Matzler K., 2014, Antecedents of M\&A success: the role of strategic complementarity, cultural fit, and degree and speed of integration, Strategic Management Journal, 35(2), pp. 269-291.

Bedyńska S., Książek M., 2012, Statystyczny drogowskaz: praktyczny przewodnik wykorzystania modeli regresji oraz równań strukturalnych, Wydawnictwo Akademickie Sedno, Warszawa.

Bobrowski M., Rodzińska-Szary P., Krampus-Sepielak A., Śliwiński M., Rudnicki S., 2018, Kondycja polskiej branży gier. Raport 2017 [dostęp: https://www.cdprojekt.com/pl/wp-content/uploads-pl/2016/03/kondycja-polskiej-branzy-gier17. pdf; 23.02.2018r.].

Cameron K.S., Quinn R.E., 2003, Kultura organizacyjna - diagnoza i zmiana. Model wartości konkurujących, Oficyna Ekonomiczna, Kraków.

Cartwright S., Cooper C.L., 1993, The role of culture compatibility in a successful organizational marriage, Academy of Management Perspectives, 7(2), pp. 57-70.

Chin K.S., Chan B.L., Lam P.K., 2008, Identifying and prioritizing critical success factors for coopetition strategy, Industrial Management \& Data Systems, 108(4), pp. 437-454

Czakon W., 2012, Sieci w zarzadzaniu strategicznym, Wolters Kluwer, Warszawa.

Denison D.R., 1996, What is the difference between organizational culture and organizational climate? A native's point of view on a decade of paradigm wars, Academy of Management Review, 21(3), pp. 619-654.

Dymek M., 2012, Video Games a Subcultural Industry, [in:] P. Zackariasson, T.L. Wilson (eds), The Video Game Industry. Formation, Present State, and Future, Routledge, New York, pp. 34-56.

Eckenhofer E., Ershova M., 2011, Organizational culture as the driver of dense intra-organizational networks, Journal of Competitiveness, 3(2), pp. 28-42.
Feijoó C., 2012, An Exploration of the Mobile Gaming Ecosystem from the Developers' Perspective, [in:] P. Zackariasson, T. Wilson (eds), The Video Game Industry: Formation, Present State and Future, New York.

Global Games Market Report 2018, NewZoo [https://newzoo. $\mathrm{com} /$ solutions/standard/market-forecasts/global-games-market-report/, access: 08/27/2018].

Gregory B.T., Harris S.G., Armenakis A.A., Shook C.L., 2009, Organizational culture and e-effectiveness: a study of values, attitudes, and organizational outcomes, Journal of Business Research, 62(7), pp. 673-679.

Hofstede G., 1998, Attitudes, values and organizational culture: disentangling the concepts, Organization Studies, 19(3), pp. 477-493.

Karsmakers N., 2010, Strategic Alliances in the Dutch Video Game Industry: An Empirical Study of Transitory Alliances in Turbulent Business Environments, LAP Lambert Academic Publishing, Saarsbrucken.

Klimas P., 2014, Kultura organizacyjna $w$ sieciach innowacji, Studia Ekonomiczne, 202, pp. 100-112.

Klimas P., 2016, Organizational culture and coopetition: an exploratory study of the features, models and role in the Polish Aviation Industry, Industrial Marketing Management, 53, pp. 91-102.

Marchand A., Hennig-Thurau T., 2013, Value creation in the video game industry: industry economics, consumer benefits, and research opportunities, Journal of Interactive Marketing, 27, pp. 141-157.

Noorderhaven N.G., Koen C.I., Beugelsdijk S., 2002, Organizational Culture and Network Embeddedness, Discussion Paper, 91 [https://core.ac.uk/download/pdf/6651191.pdf, access: 06/05/2017].

Oyserman D., 2011, Culture as situated cognition: cultural mindsets, cultural fluency, and meaning making, European Review of Social Psychology, 22(1), pp. 164-214.

Ozeren E., Ozmen O.N.T., Appolloni A., 2013, The relationship between cultural tightness-looseness and organizational innovativeness: A comparative research into the turkish and italian marble industries, Transition Studies Review, 19(4), pp. 475-492.

Pothukuchi V., Damanpour F., Choi J., Chen C.C., Park S.H., 2002, National and organizational culture differences and international joint venture performance, Journal of International Business Studies, 33(2), pp. 243-265.

Sikorski Cz., 2002, Kultura organizacyjna, C.H. Beck, Warszawa.

Strese S., Meuer M.W., Flatten T.C., Brettel M., 2016, Organizational antecedents of cross-functional coopetition: the impact of leadership and organizational structure on cross-functional coopetition, Industrial Marketing Management, 53, pp. $42-55$.

Sułkowski Ł., 2008, Czy warto zajmować się kultura organizacyj$n q$ ? Zarządzanie Zasobami Ludzkimi, 6, pp. 9-25.

Weber Y., Shenkar O., Raveh A., 1996, National and corporate cultural fit in mergers/acquisitions: an exploratory study, Management Science, 42(8), pp. 1215-1227.

Xiao Z., Tsui A.S., 2007, When brokers may not work: the cultural contingency of social capital in chinese high-tech firms, Administrative Science Quarterly, 52, pp. 1-31. 


\section{DOPASOWANIE KULTUROWE WE WSPÓLPRACY MIEDZYORGANIZACYJNEJ - PROFIL KULTUROWY TWÓRCÓW GIER W ŚWIETLE BADAŃ EMPIRYCZNYCH}

Streszczenie: Podejście relacyjne wskazuje, że dopasowanie kulturowe wpływa na nawiązywanie współpracy oraz optymalizację jej efektów. Zakłada się, że znajomość typowego profilu kulturowego pozwala organizacjom zorientowanym na współpracę dostosować własny profil kulturowy, a tym samym zwiększyć dopasowanie kulturowe i ułatwić współdziałanie. Dopasowanie kulturowe nabiera znaczenia przede wszystkim na rynkach sprzyjających współdziałaniu, tj. dynamicznych, wysokotechnologicznych i innowacyjnych, stąd też proces badawczy osadzono w branży gier. Wyniki badań rozpoznawczych wyłaniają najbardziej typowe cechy, wartości konkurujące oraz modele kulturowe twórców gier, wskazując na różnice pomiędzy twórcami gier premium (gry płatne) oraz F2P (gry bezpłatne). Generalnie kultury organizacyjne twórców gier opierają się na elastyczności i najczęściej są zbieżne z modelem adhokracji.

Słowa kluczowe: współpraca strategiczna, sieci międzyorganizacyjne, kultura organizacyjna, dopasowanie kulturowe, podobieństwo kulturowe. 